\author{
Oleksandr Poliakov ${ }^{1}$
}

DOI: https://doi.org/10.15804/rop2021208

\title{
THE HISTORICAL LEGAL RELATIONSHIP BETWEEN THE ESTABLISHMENT OF TAX AND DECENTRALIZATION PROCESSES WITHIN THE FIRST STATE ENTITIES ON THE TERRITORY OF UKRAINE
}

Key words: Decentralization, taxation, distribution of power, people's power, tax authorities, local finance, local taxes and fees.

\begin{abstract}
The scientific article is devoted to the issue of the disclosure of the processes of establishment and development of decentralization and taxation during the times of the Ants State, Kievan Rus and Principality of Galicia-Volhynia, as well as the determination of the relationship between these two processes. Due to the study of the topic of the article through the prism of various historical developments, it is possible to trace the formation and development of the tax institute in the first state institutions on the territory of modern Ukraine, as well as the form of the exercise of the people's power and its significance in the decision-making of both state-wide decisions and the resolution of issues of local importance.

The role and significance of local authorities and issues that could be resolved by the then bodies of the people's administration are revealed, and at the same time relations between the central authorities and the authorities of territorial communities are covered. Attention is paid to the law enforcement in the development of the people's administration, taxation and their relationship between the state entities of the investigated historical epochs.

Among other things, the article is devoted to establishment of a clear link between the gradual transition of power from the bodies of the people's rule to the central apparatus in the person of the prince and his surroundings and, as a result, the necessity of permanent resources, at the expense of which it would be possible to keep them. The article analyzes the reasons for the necessity of revenue receipts and the main types of revenue receipts of the time, as well as
\end{abstract}

1 Leading Legal Advisor, LLC Phenomena, poliakov.ol.petrovich@gmail.com. ORCID: 0000-0002-1710-0732. 
the bodies on which the duties of tax collection were imposed. Attention is paid to the definition of such tax characteristics as collection bodies, collection form, documentary fixing and further distribution and use of taxes.

As a conclusion of the research, the author has formed a table with indication of the basic types of revenue receipts of a given period and level of decentralization in such period, and also has made generalization of the connection of these two processes.

\section{INTRODUCTION}

Tax revenues are not one hundred years old and have long been viewed by the central government, no matter how much centralization they are characterized, as the main source of state budget revenues. Despite the sufficient number of scientific works devoted to the historical aspect of tax formation and development in Ukraine, no scientist has yet paid attention to and clearly investigated the relationship and influence of tax development and decentralization in Ukraine in various historical periods.

The relevance of the described perspective of the topic is to try to reveal the nature, purpose and types of taxes in different historical stages of Ukraine through the prism of building relations between central and local government and forming a sufficient financial base to meet public needs of the relevant administrative unit. Because, according to the author, such influence is tangible and in many respects decisive for the decentralization reform that is currently taking place in Ukraine.

To date, the analysis of the comparison of the impact of decentralization and taxes on the development of the relevant administrative-territorial unit and meeting the public needs of the population has not been paid enough attention, especially regarding the monitoring of stages of formation and strengthening of decentralization in Ukraine and related local taxation. That is why the topic is relevant today given that the reform of decentralization in Ukraine is being actively implemented right now.

The purpose of this scientific work is to conduct a theoretical and legal analysis of the relationship between the formation and development of taxation and decentralization in Ukraine and their impact on the formation of financial capacity of administrative-territorial units and the volume of public needs. 
The research used the historical and legal method, as well as the method of analysis and synthesis.

\section{THE PROCESSES OF DECENTRALIZATION IN THE PROTO STATE}

When studying the balance between the trends of concentration of power in the hands of a strong self-government or a group of people and decentralization of power, attention should be paid to the state-linked institutions that appeared on the territory of modern Ukraine. In particular, the author of the thesis "Concept of decentralization of public authority in the political-administrative tradition of Ukraine" Manuilova K.V., expresses the opinion that some principles of decentralization of public authority appeared in the day of the first settlements of eastern slavs, as well as during the period of the first state formations of the proto-Ukrainians. In particular, the researcher identifies such signs of decentralization of political order of the Ants state as collective management of the state (viche, rada) and functioning of local self-government of the ants (Manuilova, 2018, p. 315)

In the specified period, a clear relationship and mutual dependence between the principles of power distribution and the principles of taxation of the population are being investigated. Thus, in the period of state formation, when in fact there was no need for a strong authority center, which could give a response to external danger in the form of hostile tribes and unite the territorial community to achieve common goals, there is no need for analogues of modern taxes and duties. This connection is easily explained, as there is no need to maintain military force, as well as the need to maintain a single leader of the territorial community and its surroundings. That is, we can note that the emergence of taxation has accelerated the process of concentration of power in the hands of one leader or group of people who needed to determine the source of sufficient, and what is the most important, constant, replenishment of money or natural resources of treasury. This factor is also caused by the unsustainable nature of taxation, which can be traced at the first stages of state development. 
As soon as there is an external threat and as a result the necessity of forming and maintaining own force, which would have the opportunity to give a vacation, there is a mechanism of accumulation of the resource as taxes and collection from the population of the territory concerned. Other researchers can draw conclusions to confirm the above. In particular, according to Lutyi I.O., the main reason for the introduction of permanent taxes, and further replacement of domain income by local taxes is the need to maintain a stable army and finance long-term wars (Lutyi, 2009) Thus, we conclude that external threats call for the concentration of power in the hands of one or a small group of people, with the simultaneous introduction of the need to collect some of their resources from the population to ensure their existence and functioning.

\section{ESTABLISHMENT OF TAXATION AND PEOPLE'S POWER IN THE KIEVAN RUS}

Due to the necessity of permanent protection from enemies and provision of vital activity of the population a full-fledged state establishment Kievan Rus - appears on the territory of Ukraine. The latter successfully combined two trends of power distribution:

i) the power of the prince, on which the duties of command of military force and protection of territories from the encroachment of hostile tribes were laid;

ii) the power of the people, which was manifested in the form of viche and national assembly and which independently addressed problems of local importance, and also played a decisive role in solving such national issues as the election of a new prince or the announcement of military campaigns.

According to Dmitry Doroshenko: "The authority of the higher was to declare military campaigns, establish international relations, hire a prince or drive him, etc. The calling of the viche was not systematic and exceptional. For example, if you choose a prince or vice versa, you can remove an unwanted ruler, or in case of a military necessity or an urgent need for change (Doroshenko, 1992, p. 52) 
As for the tax system, in Kievan Rus, at the early stages of formation of state the payments were natural, i.e. products of agriculture and results of various kinds of industries, such as honey, bread, furs. They were exacted in two ways: by povoz (agricultural goods), when they were brought to Kiev and by poluddia (people), when the prince together with his armed force (druzhyna) went on the territories under control (Yanishevs'ka, 2012)

The norms of taxation have got their expression in the construction of the laws of the Kievan Rus - "the Russian Truth", or more precisely one of its parts - "Pokon Virnyi (the Law is faithful)". This document established the distribution of tax revenues, which was followed by a third in favor of the prince, the other part went to the armed force (druzhyna) and the authorities. There was also a tax unit - a household, which disposed of about 15 hectares of land. In addition, the source of income was recognized as trade duties, duties for organizing trading, court fees and fines. The latter were divided into vira - a fine for murder, and sale - a fine for other crimes. (Doroshenko, 1992) Thus, tax revenues were directed solely at the maintenance of the central apparatus of power and armed force (druzhyna) and were a kind of payment for protection of territorial communities from external threats and their security. This explains the lack of the need to direct funds to address the immediate needs of local population and to direct some tax revenues to address the issues of territorial communities. In fact, we can assert the existence of mutually beneficial cooperation between the central apparatus of power and the authorities of territorial communities in Kievan Rus. At that, at the first stages of the emergence and existence of Rus, the authorities of the latter were dominant and could influence all important issues, including of national importance. In particular, William Edward David Allen notes: "Kiev looked at the prince as a "hired military commander", the main task of which was considered "to care for the security of the Rus land and to fight against pagans". During the reign of prince Svyatoslav kievans were dissatisfied with them because they believed that he did not fulfill his duties. He left on a distant campaign and left Kiev to its fate, and the city had to defend itself from the rechenegs: "Prince, you have left in foreign lands and forgot about your own" (Uil'yam Edvar, 2016, p. 21) 
It can be noted that the people's rule in Rus played a role of restraining force and had real opportunities to prevent excessive concentration of power in the hands of the prince and his orbit. This situation is also observed in tax matters. If the number or size of taxes did not satisfy local communities, they boldly opposed this and forced the prince to act. The most striking example of such performances is the rebellion of the villagers against Prince Ihor in 945. The reason for this act was the desire of the prince and his armed force to exact the tribute out of the lands of the tribes, which had already been obliged to pay the debts of his warrior Sveneld (Yaroshenko, Volodymyr Pavlenko \& Vita Pavlenko, 2012)

Tax authorities during the time of Kievan Rus were concentrated in the person of prince, who delegated authority to levy taxes to bodies, officials and power-holders. All of them were in fact collection of payments without clearly defined powers (Oliynyk, 2015) According to historians: "The Prince united all power in his hands - military, administrative and judicial, and in theory had to perform all functions of the chief ruler in the court, which could be put under his authority only in case of his absence" (Doroshenko, 1992, p. 71) The governors (posadnyky) were appointed to important centers of Kiev Rus and assigned judicial functions and powers to collect duties and tributes, and were the governors of rural areas. In addition, in every village (pohost) were assistants of the landholders and the power-holders - the bodies that had exclusive tax competence (Tatsiy, Rohozhyna \& Honcharenko, 2003) The contemporary administrative-territorial system had a military character and divided into thousands, hundreds and tens. Taxation in turn was carried out at the level of hundreds. Accordingly, the most authoritative powers were the thousand or the military, who carried out military and administrative functions at the level of thousands. The letters also mention the so-called landholders, who managed smaller districts, were city commentators (Doroshenko, 1992)

That is, the tax system of the Kievan Rus, which was launched as a robbery of subordinate tribes gradually began to acquire modern characters: The dates of the tributes and their size are established, the natural character is gradually replaced by money, the centers of gathering of tributes guests and especially responsible for them - bodies are created. However, 
there was no clear system of taxation and their administration. The fulfillment of tax duties was based on the military rule, and all receipts were actually on the maintenance of the prince and his court, together with his armed force. The period described can be characterized by the institutional lack of a tax system, which in fact was forced, was not perceived by the population because actually did not go on improving their lives. It is interesting to consider the fact that one of the main directions of expenses of tax receipts - the Prince's armed force, was at the same time the body of collecting these receipts. This procedure clearly investigates the interest in the amount of taxes levied, which often led to social tension in society.

Thus, during the time of Kievan Rus people's power in the form of viche, had real influence on national policy, including tax collection, and it was an effective prevention of excessive concentration of power in the hands of a certain group of people. Moreover, some researchers point out that the authority of Kiev princes Askold and Dir, Oleh, Ihor, Olga, Svyatoslav (864-972) was nominal, their function was to protect the borders, and the state policy was often decided at the national meetings (Uil'yam Edvar, 2016) English scientist William Edward David Allen in his work "the South Russian lands from the first Kiev princes to Joseph Stalin" refers to the statement by historian Rostov: "The huge difference that existed between Kiev Rus and Western Europe is still unexplained. In the West - agriculture and feudalism, in Rus - trade and cities-states" (Uil'yam Edvar, 2016, p. 20).D. Doroshenko notes: "Although the princes considered the whole of Rus land as the property of their ancestry, they had to take very much into account the opinion of the community represented by the viche. Undoubtedly, viche as an organ of the sovereign community was an element of the old, older from the princely power, but during the period of organization of the Rus state by the varyags, during the period of unification in this state of the Rus tribes with the help of the "command", that is, the weapon force, government of the prince overdid. Kiev state of the first princes was rather well centralized (at the times of Vladimir the Great and Yaroslav), and the viche remains in the shadow, playing the role in local life only, as the body of local self-government. But with the weakening of Kiev's centralism on Yaroslav's death, it again stands on the political arena" (Doroshenko, 1992, p.69) 
However, it should be noted that the mentioned forms of the people's administration were not able to form and consolidate their status in the form of permanent institutions, which is possible to consider a significant loss, since at the same time different forms of people's administration were actively functioning and developing in Europe, which subsequently found their manifestation in the form and active implementation of the Magdeburg Law, Ukrainian communities were unprepared to defend their interests against aggressive centralized policies of the aggressor states, which significantly slowed the development of local authorities as such.

\section{FORMS OF DECENTRALIZATION OF PRINCIPALITY OF GALICIA-VOLHYNIA}

A separate milestone in the history of the establishment of decentralization on the territory of Ukraine was the Principality of Galicia-Volhynia, which is perceived by historians as the right successor of the Kiev movement. In the study of the issue of the people's power in Galician-Volyn principality, S.Svorak notes that folk traditions of the principality were the form of adapted to the conditions that arose after the Tatar-Mongolian occupation of the Rus lands, because it was in the Principality of GaliciaVolhynia that the traditional people's power and the special role of the state productive capacity to change were localized (Svorak, 2012, p. 793) The persistence and affinity of such traditions demonstrates their preservation not only in the face of external threats, but also in the face of the struggle for power inside. In his work "Essay on the history of Ukraine" Dmitry Doroshenko notes: "Even at the times of Vladimir boyarskaya verstva acquired a very big significance, which turned little by little into family and land aristocracy from the former old friends. The boyars claimed to participate in the government, to make sure that the prince did nothing without the boyars' duma (the Council), took hold of the top governments" (Doroshenko, 1992, p. 82) Kostomarov N.I. also confirms the significant influence on management by the boyars: "The Princes who ruled Galicia were elected and dependent on the viche. Yet the viche itself was in the hands of the rich and powerful owners of land - boyars. The 
Galicia princes were so dependent on the viche that it judged not only their political activity, but also their domestic life" (Kostomarov, 1912, p. 239)

In the given period, the city became the stronghold of the people's power. The reign of Danila Galitskiy became an active step in the development and construction of the latter. Having received the right to manage the territory from Mongolian Khan, Danilo founded about seventy cities Lviv, Holm, Danilov, among them. In the "Essay on the history of Ukraine" we see the following statements: "Danilo greatly contributed to the development of cities. He founded the cities of Lviv and Holm, which were very soon settled and made significant centers of trade movement. Undoubtedly, the princes considered that cities and the urban population can serve them as a vicious in the fight against the boyars, as it has been repeatedly in reality and has happened" (Doroshenko, 1992, p. 95) According to S.D. Svorak, the construction of cities was developing a qualitatively new arrangement of political forces in Halychyna and Volyn because of the following reasons: First, the cities were the stronghold of the people's power, and secondly, the citizens were economically interested in the villagers being free and had the opportunity to exchange their products for the craft work (Svorak, 2012)

The author concludes that it was the cities that were the branches of the people's power and the centers of influence of the population on the state order. As for taxes, the ones born during the time of Rus, namely, the tax from the farmland, the human being and the plow (now land tax), remained on the territory of Halychyna and Volyn. Cities were divided into hundreds and streets, with the viche at which the aspirations of ordinary residents were expressed. From the letter by Mstislav Danilovich in 1289 it turns out that the city of Berestya was divided into hundreds: The residents had to pay the tribute "from all hundred". Another type of city organization was the city of Syanok. Residents of the city were exempt from taxes for 15 years, and after that they had to pay annually 16 hroshi every piece of land apart from gardens in the city (Kryp"yakevych, 1984) That is, it is possible to note that the people's power in Halychyna and Volyn became a kind of a new period of development of the people's power on the territory of Ukraine. And in particular, it should be empha- 
sized on such features as stability and imminence, because the people of that period were in clear opposition to the boyars and Mongolian rule, but despite the whole number of negative and restraining factors, still remained the force with which they were reckon.

\section{CONCLUSION}

Thus, according to the results of the above research, and exercising a historic method of research, it can be concluded (which is stated in the table below in addition) that during the period of beginning and development of state on the territory of modern Ukraine the processes of the development of taxation and decentralization institutions not only were related, but also immediately interrelated. Tax revenues have played an important role since the beginning of statehood, and the provisions that enshrined them were found in the first regulation acts. The existence of financially autonomous territorial communities contributed to the strong positions of decentralization and the active participation of the local population in solving national issues.

\begin{tabular}{|l|l|l|l|}
\hline $\begin{array}{c}\text { Historical } \\
\text { epoch }\end{array}$ & Main taxes & $\begin{array}{c}\text { Administrative and } \\
\text { territorial division } \\
\text { and the role of local } \\
\text { authorities }\end{array}$ & \multicolumn{1}{|c|}{ Conclusion } \\
\hline $\begin{array}{l}\text { State-linked } \\
\text { forms } \\
(\text { Ants State) }\end{array}$ & - & $\begin{array}{l}\text { Collective governing } \\
\text { by calling viche and } \\
\text { rada (councils) }\end{array}$ & $\begin{array}{l}\text { Because of no necessity of permanent } \\
\text { receipts state-linked forms did not have } \\
\text { any analogue of taxation system. One } \\
\text { more is the absence of central govern- } \\
\text { ment, as there were no challenges that } \\
\text { would promote its formation, first of all } \\
\text { outside threats and the need for territo- } \\
\text { ry defense. The issues tackling commu- } \\
\text { nity interests were solved via } \\
\text { community meetings and collective } \\
\text { decision making. }\end{array}$ \\
\hline
\end{tabular}




\begin{tabular}{|c|c|c|c|}
\hline $\begin{array}{c}\text { Historical } \\
\text { epoch }\end{array}$ & Main taxes & $\begin{array}{l}\text { Administrative and } \\
\text { territorial division } \\
\text { and the role of local } \\
\text { authorities }\end{array}$ & Conclusion \\
\hline Kievan Rus & $\begin{array}{l}\text { Taxes were from } \\
\text { gathering momen- } \\
\text { tum, were of natural } \\
\text { desultory character } \\
\text { and fell into povoz } \\
\text { (agricultural goods), } \\
\text { and poluddia (pe- } \\
\text { ople). The main func- } \\
\text { tion of the taxes was } \\
\text { the maintenance of } \\
\text { the armed force (dru- } \\
\text { zhyna) and, at the } \\
\text { times of Volodymyr, } \\
\text { the maintenance of } \\
\text { church }\end{array}$ & $\begin{array}{l}\text { The territory is divi- } \\
\text { ded into separate } \\
\text { principalities. People's } \\
\text { power is still in au- } \\
\text { thority, which reveals } \\
\text { in land communities } \\
\text { and local communi- } \\
\text { ties. In different pe- } \\
\text { riods the size and } \\
\text { significance differs. } \\
\text { However, at the height } \\
\text { of the community its } \\
\text { members were enti- } \\
\text { tled to solve the varie- } \\
\text { ty of issues such as } \\
\text { overthrowing or } \\
\text { electing a new prince. }\end{array}$ & $\begin{array}{l}\text { Despite the fact that Kievan Rus was an } \\
\text { early feudal state where prince's power } \\
\text { ran, it can be to certain extent characte- } \\
\text { rized as a decentralized aggregation of } \\
\text { separate principalities united by com- } \\
\text { mon aim-the defense of territories. The } \\
\text { power of Kievan princes was quite } \\
\text { formal and fell to the execution of } \\
\text { a defense function and collection of } \\
\text { tributes. Considering the size of the } \\
\text { state the local issues were addressed at } \\
\text { people's meetings and viche. Local } \\
\text { communities exercised wide autonomy. } \\
\text { The balance between central and local } \\
\text { authorities fully depended on the perso- } \\
\text { nality of the prince, if the one on the } \\
\text { throne was a strong and respectable } \\
\text { personality, i. e. at the times of Volody- } \\
\text { myr the Great and Yaroslav the Wise, } \\
\text { the power went to the prince. However, } \\
\text { with the appearance of less self-suffi- } \\
\text { cient rulers, collective decision making } \\
\text { by the communities took the leading } \\
\text { role. }\end{array}$ \\
\hline $\begin{array}{l}\text { Principality } \\
\text { of Galicia- } \\
\text { Volhynia }\end{array}$ & $\begin{array}{l}\text { The tax from the } \\
\text { farmland (podymne), } \\
\text { the human being } \\
\text { (poluddia) and the } \\
\text { plow (popluzhne) } \\
\text { (now land tax) }\end{array}$ & $\begin{array}{l}\text { Viche is still in autho- } \\
\text { rity to solve national } \\
\text { and local issues. } \\
\text { Despite the existence } \\
\text { of viche and prince's } \\
\text { power, boyars (well } \\
\text { off landlords) are } \\
\text { taking a leading role. }\end{array}$ & $\begin{array}{l}\text { Cities, whose population had grown } \\
\text { dramatically in that period, become the } \\
\text { stronghold of people's power. At the } \\
\text { same time, the period is marked by the } \\
\text { struggle of the prince against the boyars } \\
\text { who strongly opposed the ruler and } \\
\text { tried to influence state policies, with the } \\
\text { help of viche in particular. As an exam- } \\
\text { ple of boyars' growing influence, many } \\
\text { of them were appointed to key posi- } \\
\text { tions, as governors and thousand's. The } \\
\text { Magdeburg Law, different from city to } \\
\text { city, was being actively implemented. }\end{array}$ \\
\hline
\end{tabular}




\section{BIBLIOGRAPHY:}

Doroshenko, D.I. (1992). Narys istoriyi Ukrayiny. Tom I (do polovyny XVII stolittya). Vydannya druhe. [Essay on the history of Ukraine. Volume I (until the middle of the XVII century). Second edition.]. Kiev: Hlobus.

Kostomarov, N.I. (1912). Russkaya istoriya v zhizneopisaniyakh yeye glavneyshikh deyateley [Russian history in the biographies of its main figures]. St. Petersburg: Literary Fund.

Kryp'yakevych, I.P. (1984). Halyts'ko-Volyns'ke knyazivstvo. [Galicia-Volyn principality]. Kiev: Naukova dumka.

Lyutyy, I.O., Demydenko, L.M., Romanyuk, M.V. (2009). Podatkova systema: navchal'nyy posibnyk dlya studentiv vyshchykh navchal'nykh zakladiv [Tax system: a textbook for students of higher educational institutions]. Kiev: Tsentr uchbovoyi literatury. Manuilova K.V. (2018) Kontseptsiya detsentralizatsiyi publichnoyi vlady v politykoupravlins'kiy tradytsiyi Ukrayiny [The concept of decentralization of public power in the political and managerial tradition of Ukraine]. Zaporizhzhya: Klasychnyy pryvatnyy universytet Zaporizhzhya.

Oliynyk, O.D. (2015). Istorychnyy dosvid stanovlennya ta rozvytku fiskal'noyi sluzhby Ukrayiny [Historical experience of formation and development of the fiscal service of Ukraine]. Irpin': Natsional'nyy university DPS Ukrayiny.

Svorak, S.D. (2012). Narodovladdya Halyts'ko-Volyns'koyi derzhavy u naukovykh pohlyadakh vitchyznyanykh doslidnykiv XIX st. [Democracy of the Galicia-Volyn state in the scientific views of domestic researchers of the XIX century.]. Forum prava. Downloaded from: http://archive.nbuv.gov.ua/e-journals/FP/2012-4/12ccdvdc/pdf. Tatsiy, V.Y., Rohozhyna, A.Y., Honcharenko, V.D. (2003). Istoriya derzhavy i prava Ukrayiny. U 2 tomakh. TOM I. [History of the state and law of Ukraine. In 2 volumes. VOLUME I.]. Kiev: Kontsern «Vydavnychyy Dim «In Yure».

Uil'yam Edvar D.A. (2016). Yuzhnorusskiye zemli ot pervykh kiyevskikh knyazey do Iosifa Stalina [South Russian lands from the first Kiev princes to Joseph Stalin]. Moskva: Tsentrpoligraf.

Yanishevs'ka, K.D. (2012). Istorychni aspekty rozvytku podatkovykh orhaniv v Kyyivs'kiy Rusi [Historical aspects of the development of tax authorities in Kievan Rus]. Sumy: SumDU.

Yaroshenko, F.O., Pavlenko, V. ., Pavlenko, V.P. (2012). Istoriya podatkiv ta opodatkuvannya v Ukrayini: navchal'nyy posibnyk dlya studentiv vyshchykh navchal'nykh zakladiv. [History of taxes and taxation in Ukraine: a textbook for students of higher educational institutions]. Kiev: DP «Vydavnychyy dim «Personal». 